\title{
MARKETING 4.0 UNTUK USAHA MIKRO TAS TALI KUR DESA MOJONGAPIT KECAMATAN JOMBANG KABUPATEN JOMBANG JAWA TIMUR
}

\author{
Abid Datul Mukhoyaroh ${ }^{1}$, Ririn Susilawati ${ }^{2}$ \\ Program Studi Administrasi Bisnis, Fak Bisnis \& Bahasa, Unipdu Jombang \\ Email: ${ }^{1}$ jeng_abite@yahoo.com, ${ }^{2}$ ririnraihanun@gmail.com
}

\begin{abstract}
This community service activity aims to empower the potential of the two partners as prospective entrepreneurs of Tali Kur bags by providing training to market products (marketing 4.0) and educating good business management patterns. This is based on the problems faced by the two partners who have less knowledge about how to market this strap bag product. So both partners only have the ability to produce, and do not have the ability to sell or market their products. The constraints of the two partners do not have networks and channels in marketing their products in the digital era like now. The solutions offered include providing skills training in the field of marketing and training on good business management and making a brand for these products. The method used is to observe the production sites of the two partners, conduct interviews about the problems faced by the two partners, establish cooperation with the two partners to resolve the problem in accordance with the mutual agreement. The results obtained indicate that, the two partners are better prepared to become independent entrepreneurs by being given the knowledge of marketing management and having a business network digitally. The two partners gained an increase in the turnover of the number of sales of Tali Kur bags after implementing the 4.0 marketing concept. As a conclusion of this service activity are 4.0 marketing activities for UKM Curly strap bags in Ds Mojongapit, Kec Jombang, Kab Jombang, East Java, with training and marketing solutions 4.0 very helpful in overcoming the problems of marketing the products of the two partners.
\end{abstract}

Keywords: marketing, marketing 4.0, bag strap, micro business

\begin{abstract}
Abstrak. Marketing 4.0 Kegiatan pengabdian kepada masyarakat ini bertujuan untuk memberdayakan potensi kedua mitra sebagai calon pengusaha mandiri tas tali kur dengan memberikan pelatihan untuk memasarkan produk (marketing 4.0) dan edukasi pola manajemen usaha yang baik. Hal ini didasarkan pada permasalahan yang dihadapi oleh kedua mitra yang memiliki pengetahuan yang kurang terhadap cara memasarkan produk tas tali kur ini. Jadi kedua mitra hanya memiliki kemampuan dalam memproduksi saja, dan belum memiliki kemampuan menjual atau memasarkan produknya. Kendala kedua mitra tidak memiliki jaringan dan channel dalam pemasaran produknya di era digital seperti sekarang ini. Solusi yang ditawarkan diantaranya adalah memberikan pelatihan ketrampilan dalam bidang pemasaran dan pelatihan tentang manajemen usaha yang baik serta membuatkan merek untuk produk tas tali kur ini. Metode yang digunakan adalah melakukan observasi ke tempat produksi kedua mitra, melakukan wawancara tentang permasalahan yang dihadapi kedua mitra, menjalin kerjasama dengan kedua mitra untuk menyelesaikan permasalahan sesuai dengan kesepakatan bersama. Hasil yang diperoleh menunjukkan bahwa, kedua mitra lebih siap menjadi pengusaha mandiri dengan diberikan bekal pengetahuan menajemen pemasaran dan memiliki jaringan usaha secara digital. Kedua mitra memperoleh peningkatan omzet jumlah penjualan tas tali kur setelah menerapkan konsep marketing 4.0. Sebagai kesimpulan dari kegiatan pengabdian ini adalah kegiatan marketing 4.0 untuk UKM Tas tali kur di Ds Mojongapit, Kec Jombang, Kab Jombang Jawa Timur, dengan adanya pelatihan dan solusi marketing 4.0 sangat membantu mengatasi permasalahan pemasaran produk kedua mitra.
\end{abstract}

Keywords: marketing, marketing 4.0, tas tali kur, usaha mikro 


\section{PENDAHULUAN \\ Analisis Situasi}

Perekonomian dunia, khususnya negaranegara berkembang seperti Indonesia, sedang bergerak menuju era pemasaran digital. Perkembangan teknologi menjadi penggerak pertama perubahan tersebut. Organisasi dunia OECD (Organization for Economic Cooperation and Development) menyatakan, inovasi digital diklaim mampu membawa banyak negara lebih dekat pada kemakmuran yang berkesinambungan.

Gagasan tersebut tak bisa disangkal mengingat teknologi telah membuat proses produksi, pemasaran, distribusi, dan sebagainya menjadi lebih efisien dan efektif. Konektivitas yang dibangun pun memampukan banyak pelaku bisnis terhubung dengan akses-akses modal dan pasar yang baru. Peluang-peluang bisnis baru pun terbentang lebar dan pemasaran digital hadir sembari menjanjikan kemakmuran. Teknologi ini membantu mengembangkan sektor-sektor ekonomi, seperti sektor ritel dengan e-commerce, transportasi dengan kendaraan automatis, pendidikan dengan aneka kursus online, kesehatan, sampai interaksi sosial melalui media sosial.

Itulah kondisi di era transisi dari tradisional menuju era digital. Dalam konteks ini, dibutuhkan pendekatan pemasaran baru untuk membantu pemasar dalam mengatisipasi dan mengelola dampak teknologi yang disruptif tersebut.

Marketing 4.0 merupakan pendekatan pemasaran yang mengkombinasikan interaksi online dan interaksi offline antara perusahaan dengan pelanggan. Secara umum, Marketing 4.0 bisa dipahami seperti itu. Di era ekonomi digital, interaksi digital saja tidaklah cukup. Kenyataannya, justru di saat dunia online berkembang, sentuhan offline menjadi titik diferensiasi yang kuat.

Selain mengkombinasikan online dan offline, Marketing 4.0 juga mengintegrasikan antara style dan substance. Artinya, merek tidak hanya mengedepankan branding bagus, tetapi juga konten yang relevan dengan pelanggan atau menyuguhkan konten yang bagus dengan kemasan yang up-to-date dan bagus.

Marketing 4.0 juga mengembangkan konektivitas machine-to-machine dan artificial intelligence dalam rangka mendongkrak produktivitas. Tetapi, itu harus diimbangi dengan pengembangkan konektivitas human-to-human yang justru akan memperkuat customer engagement. Intinya, pengembangan teknologi tidak berhenti pada teknologi itu sendiri, tapi bagaimana teknologi ini membantu merek dalam memanusiakan relasi dengan para pelanggannya.

Usaha Mikro/ UKM memiliki peran penting dalam laju ekonomi Indonesia terutama dalam penciptaan lapangan kerja dan pemberdayaan rumah tangga yang mendukung pendapatan rumah tangga. Keberadaan UKM diharapkan mampu memacu perekonomian di tengah perlambatan ekonomi yang terjadi saat ini. Pemanfaatan konsep marketing 4.0 memberikan harapan bagi UKM untuk berkembang menjadi pusat kekuatan ekonomi.

Era digital memang tidak mungkin untuk dihindari, maka pelaku UKM harus mampu memaksimalkan manfaat perkembangan teknologi untuk kemajuan usahanya, seperti UKM tas tali kur yang ada di Desa Mojongapit Kecamatan Jombang Kabupaten Jombang ini.

Tas berbahan dasar tali kur atau drawstring adalah tas yang terbuat dari tali kemudian dirangkai menjadi tas yang unik. Tas tali kur merupakan salah satu jenis tas hasil kerajinan tangan yang memiliki nilai eksklusifitas tinggi. Ekslusif karena dari segi bentuk atau model, tas tali kur ini menawarkan berbagai macam bentuk yang sangat variatif dengan didukung banyak pilihan warna. Keunggulan bersaing dari tas tali kur justru terletak dari proses pembuatannya yang dibuat secara manual dengan tangan, bukan dengan mesin, seribu tas persis sama bisa dibuat dengan menggunakan mesin, seribu tas persis sama bisa diproduksi dalam waktu yang sangat singkat, tetapi tas yang dibuat dengan tangan tentu tidak bisa, hampir 100 persen pengerjaan tas tali kur ini mengandalkan ketrampilan merajut. Keorisinalitas-an tas tali kur ini menjadi magnet daya saing untuk bersaing dengan tas-tas buatan pabrik.

Tas wanita berbahan dasar tali kur ini sangat potensial di pasar. Tas tali kur memiliki banyak sekali kelebihan, diantaranya adalah bahannya yang sangat kuat menjadikan tas ini lebih awet dan tahan lama. Tas tali kur juga terkesan simple, elegant dan cocok dikenakan dalam berbagai acara. Tas dari tali kur ini dirangkai dan disusun dengan rapi serta dimodifikasi dengan tambahan asesoris rajutan bunga yang kemudian dikombinasikan dengan tas tali kur yang membuat tas ini semakin cantik dan menawan. Namun setiap produk, tentulah 
memiliki kekurangan. Kekurangan dari tas tali kur ini adalah pembuatannya yang cukup rumit untuk dikerjakan, karena membutuhkan kesabaran, ketelitian, dan ketelatenan dalam pembuatannya. Tingkat kesulitan dalam merangkai tas tali kur inilah yang menentukan harga jual tas. Apabila tingkat kesulitannya tinggi, maka pada umumnya harganya juga semakin tinggi. Tas tali kur ini meski dibuat dengan tangan atau handmade, harga yang dibandrol cukup terjangkau, yaitu antara $\mathrm{Rp}$. 100.000 - Rp. 500.000, sehingga siapapun bisa membeli dan memiliki tas tali kur ini.

Dengan perubahan dunia usaha yang semakin kompleks dengan ditandai dengan perubahan era pemasaran traditional ke pemasaran digital atau biasa disebut dengan era marketing 4.0, maka kondisi ini membuat semua produk menjadi bersaing dengan sangat ketat. Menjawab tantangan era pemasaran ini, maka UKM pun harus siap untuk berjuang memenangkan persaingan usaha, dengan cara meningkatkan daya saing melalui peningkatan kualitas dan kuantitas produksi tas tali kur ini.

\section{Permasalahan Mitra}

Permasalahan prioritas dari kedua mitra adalah tidak memiliki kemampuan dalam manajemen pemasaran atau memasarkan produksi tas tali kurnya. Hal ini dilihat dari tipe pengerjaan tas tali kur nya yang cenderung kedua mitra akan memproduksi manakala ada teman atau rekanan yang memesan, dan bukan kedua mitra yang jemput bola kepada pembeli atau mencoba memasarkan/ mencari calon pembeli. Permasalahan prioritas tersebut telah disepakati antara kedua mitra dengan tim pelaksana program PKM untuk diselesaikan selama pelaksanaan kegiatan pengabdian kepada masyarakat ini. Kebutuhan kedua mitra adalah terbentuknya kemandirian secara ekonomi melalui produksi tas tali kur berskala mikro dengan kemampuan memasarkan produk dengan baik.

Permasalahan peningkatan daya saing melalui peningkatan kuantitas dan kualitas produk tas tali kur yang dihadapi oleh kedua mitra juga menjadi permasalahan prioritas lainnya untuk diselesaikan selama pelaksanaan program PKM ini. Melalui program PKM ini, kedua mitra diharapkan dapat memperoleh pemahaman tentang kualitas dan kuantitas produksi tas agar hasil produksi tas yang dihasilkan semakin baik dan memiliki daya saing tinggi.
Permasalahan Iptek melalui pemahaman dan penerapan manajemen usaha, juga menjadi perhatian dan capaian dalam program PKM ini. Melalui pelatihan pemahaman manajemen usaha yang baik, diharapkan kedua mitra menjadi memiliki perencanaan usaha, dan memiliki perhitungan akan margin laba yang harus diperoleh, yaitu dengan memisahkan antara profit berdagang tas dan biaya kebutuhan hidup keluarga sehingga kedua mitra dapat menghitung modal dan anggaran yang harus dikeluarkan setiap bulan agar produksi tas tetap tinggi. Kedua mitra merupakan pengusaha mikro jika dilihat dari beberapa faktor, misalnya jiwa wirausaha yang belum memadai, tingkat pendidikan relatif rendah, perencanaan usaha yang belum memadai, belum maksimalnya manajemen usaha, serta tidak memiliki pengelolaan pemasaran. Oleh karena itu, kedua mitra membutuhkan sentuhan iptek dari rencana pelaksanaan program PKM ini yang akan difokuskan pada segi sumber daya manusia, sarana dan prasarana, produksi, serta manajemen usaha.

\section{SOLUSI DAN TARGET LUARAN}

Rencana program PKM yang diusulkan ini diharapkan dapat menyelesaikan permasalahan yang dihadapi oleh kedua mitra sehingga tercapai tujuan kegiatan pengabdian ini untuk masyarakat yang produktif secara ekonomi (usaha mikro) produk tas tali kur ini. Solusi yang ditawarkan kepada kedua mitra berdasarkan permasalahan yang dihadapi dapat dijabarkan sebagai berikut :

1 Workshop peningkatan daya saing melalui peningkatan kualitas dan kuantitas produk

2 Focus Group Discussion untuk menentukan, merumuskan strategi marketing 4.0 yang sesuai dengan usaha mikro tas tali kur. Pemilihan saluran pemasaran dan jaringan usaha untuk kedua mitra. Luaran untuk solusi ini adalah kedua mitra mendapatkan pemahaman saluran atau media promosi yang tepat untuk mempromosikan produknya, kedua mitra juga mendapatkan solusi jaringan usaha atau networking untuk area promosi produk-produknya.

3 Pembuatan merek produk untuk tas tali kur. Luaran untuk solusi ini adalah kedua mitra menjadi memiliki merek untuk identitas produknya, merek yang mudah diingat, dikenal dan menarik konsumen.

4 Modul marketing 4.0 untuk usaha mikro.

\section{METODE PELAKSANAAN}

Metode pelaksanaan kegiatan pengabdian kepada masyarakat ini dapat dijelaskan melalui 
tahapan atau langkah-langkah dalam melaksanakan solusi yang ditawarkan untuk mengatasi permasalahan kedua mitra. Langkahlangkah penyelesaian masalah kedua mitra dijabarkan berdasarkan permasalahan dalam bidang sumber daya manusia, sarana dan prasarana, produksi dan manajemen.

Permasalahan Mitra dalam bidang Sumber daya, metode penyelesaiannya dengan Mengadakan pelatihan untuk mitra tentang manajemen usaha. Partisipasi mitra adalah mengikuti pelatihan tersebut dan mencatat hal-hal penting selama pelatihan.

Permasalahan Mitra dalam bidang sarana dan prasarana yaitu dengan Penyediaan alat pembuat tas tali kur, yaitu tali kur berbagai warna, korek api, ring tas, handle tas, kain furing, lem, resleting, dan benang jahit dan pembuatan akun di media sosial untuk sarana dan prasarana promosi marketing 4.0

Permasalahan mitra dalam bidang Produksi, yaitu dengan Membuat variasi modelmodel tas tali kur yang akan dijual oleh kedua mitra. Kedua mitra akan menjual jenis variasi kreasi model tas tali kur yang berbeda dengan kekhasan masing-masing. Dan mengadakan Workshop peningkatan daya saing produk melalui peningkatan kualitas dan kuantitas produk. Mitra akan mendapatkan peningkatan kualitas dan kuantitas produksi tas tali kur seperti metode pembuatan tas tali kur yang lebih cepat dan efisien, pemahaman tentang pemilihan bahan, pemahaman tentang pemilihan komposisi warna, penambahan ide model, kreasi dan kreativitas pada tas tali kur. Dan melakukan evaluasi terkait dengan temuan-temuan selama pelaksanaan pelatihan, serta mengukur ketercapaian tingkat produksi yang berhasil dihasilkan oleh kedua mitra. Kegiatan pengabdian kepada masyarakat ini akan tetap dilanjutkan meskipun program PKM ini telah selesai.

Permasahan mitra di bidang manajemen, yaitu dengan Mengadakan pelatihan tentang penerapan sistem manajemen pemasaran oleh ahli manajemen pemasaran dari Fakultas Bisnis dan Bahasa, Universitas Pesantren Tinggi Darul Ulum Jombang dan Melakukan pemilihan saluran pemasaran dan jaringan usaha untuk kedua mitra.

\section{HASIL DAN PEMBAHASAN}

Pelaksanaan kegiatan Pengabdian

Kepada Masyarakat dengan judul: Marketing 4.0 Untuk Usaha Tas Tali Kur Desa Mojongapit Kecamatan Jombang Kabupaten Jombang Jawa Timur ini memiliki hasil yang cukup baik, hal ini didasarkan pada permasalahan yang dimiliki mitra dan solusi yang diberikan, diantaranya yaitu :

1. Permasalahan mitra yang pertama adalah tidak memiliki kemampuan dalam manajemen pemasaran atau memasarkan produksi tas tali kur nya, jadi mitra hanya bisa memproduksi atau membuat tas tali kur saja. Terlebih lagi, sekarang dunia pemasaran sedang memasuki era revolusi bisnis yaitu marketing 4.0. Dengan adanya kegiatan PKM ini mitra menjadi tahu pentingnya memahami dan memiliki startegi pemasaran yang baik atau dalam hal ini adalah strategi marketing 4.0

2. Permasalahan mitra yang kedua adalah kaitannya dalam peningkatan daya saing. Daya saing dalam hal peningkatan kualitas produksi tas tali kur dan kuantitas produksi tas tali kur. Hal ini menjadi penting karena perubahan lanskap dunia bisnis dengan berbagai kecanggihan teknologi yang ada, menuntut para pelaku bisnis dan UKM untuk bersaing lebih ketat. Kecanggihan teknologi membuat para konsumen bisa mengakses dan mengetahui kualitas barang yang akan dia beli. Melihat kondisi pasar yang seperti ini, maka mutlak adanya kalau para pelaku UKM harus semakin meningkatkan daya saing produknya melalui peningkatan kualitas dan kuantitas produk tas tali kur. Dengan adanya PKM ini, mitra menjadi memiliki tambahan ketrampilan tentang pembuatan tas tali kur baik dari segi desain, maupun pemilihan tata warna.

3. Permasalahan mitra yang ketiga adalah dalam hal pemahaman dan penerapan manajemen usaha. Manajemen usaha disini meliputi pemberian pengertian tentang cara pengelolaan manajemen bisnis yang baik, beserta perumusan strategi marketing 4.0 yang sesuai dengan kebutuhan masingmasing mitra. Dengan adanya kegiatan PKM ini, mitra menjadi mengetahui dan memahami tentang pola manajemen dari perencanaan maupun pengrganisasian maupun pengawasan nya.

\section{Luaran Yang Dicapai}

Luaran dari Program Kemitraan Masyarakat ini bertujuan untuk menyelesaikan permasalahan yang dihadapi oleh kedua mitra sehingga tercapai tujuan kegiatan pengabdian ini untuk masyarakat yang produktif secara ekonomi (usaha mikro) produk tas tali kur ini. Luaran yang sudah dilakukan selama kurun waktu 5 bulan ini adalah : 
1. Pelaksanaan perbaikan tata nilai masyarakat khususnya dalam bidang sosial dan pendidikan melalui peningkatan mutu sumber daya manusia dalam bidang wirausaha. Luaran dari solusi ini adalah kualitas pengetahuan khususnya dalam bidang marketing menjadi meningkat. Kedua mitra menjadi tahu apa pentingnya marketing atau ilmu pemasaran dalam bisnis atau usaha tas tali kur.

2. Pelaksanaan perumusan strategi marketing 4.0 untuk menentukan strategi marketing focus sesuai dengan keluhan dan kebutuhan masing-masing mitra. Untuk masing-masing mitra diadakan dua kali pelaksanaan diskusi perumusan strategi marketing 4.0.

3. Focus group discussion dengan kedua mitra (mitra 1 dan mitra 2) dalam memahami perumusan strategi marketing 4.0. Jadi dalam focus group discussion ini, kedua mitra dipertemukan untuk saling sharing dan tukar pengalaman seputar manajemen pemasaran.

4. Publikasi Ilmiah pada Prosiding dalam Seminar Nasional Hasil Pengabdian Masyarakat sebagai luaran PKM dengan judul Marketing 4.0 Untuk Usaha Mikro Tas Tali Kur Desa Mojongapit Kecamatan Jombang Kabupaten Jombang, dengan status submitted.

\section{SIMPULAN DAN SARAN Simpulan}

Kesimpulan dalam pelaksanaan kegiatan Program Kemitraan Masyarakat dengan judul Marketing 4.0 Untuk Usaha Tas Tali Kur Desa Mojongapit Kecamatan Jombang Kabupaten Jombang, adalah mitra sangat antusias dalam kegiatan PKM ini, kedua mitra juga menyambut baik dan mengikuti dengan tertib semua kegiatan yang berlangsung. Kedua mitra merasa terbantu dengan adanya kegiatan Program Kemitraan Masyarakat. Dengan adanya kegiatan PKM ini, kedua mitra menjadi tahu cara-cara atau strategi memasarakan produk tas tali kur yang selama ini diproduksi. kedua mitra menjadi memiliki strategi bersaing di tengah kecanggihan teknologi yang ada, melalui strategi bersaing marketing 4.0.

\section{Saran}

Saran dari kegiatan Program Kemitraan Masyarakat Marketing 4.0 Untuk Usaha Tas Tali Kur Desa Mojongapit Kecamatan Jombang Kabupaten Jombang ini adalah pemahaman kedua mitra tentang IT yang masih kurang, jadi tim PKM agak kesulitan dalam menjelaskan strategi marketing 4.0 yang berbasis IT. Oleh karena itu, kedua mitra berharap masih akan mendapat perhatian dan pantauan akan strategi marketing 4.0 yang sedang dilakukan. Harapan lainnya kedua mitra berharap kegiatan yang serupa akan ada lagi di tahun-tahun yang akan datang.

\section{DAFTAR PUSTAKA}

Eko, Aditya. 2017. Tas Tali Kur Bikin Ibu Rumah

Tangga Berdaya. Jombang: Majalah Suara

Pendidikan Edisi: 56/ tahun V/ April

2017 halaman 28

Hafnur, Yanti. 2009. Tas Rajutan Gaya. Jakarta:

Kriya Pustaka

Kotler, Philip \& Kevin Lane Keller. 2007. Manajemen Pemasaran, Edisi Kedua Belas Jilid 1. Jakarta: Erlangga

-------, Philip \& Kevin Lane Keller. 2009. Manajemen Pemasaran, Edisi Ketiga Belas Jilid 2. Jakarta: Erlangga

-------, Philip, Hermawan Kertajaya \& Iwan Setiawan. 2017. Marketing 4.0 Moving From Traditional to Digital. New Jersey: Wiley

Shofiana, Dina Eka \& Ririn S. 2016. Kawista (Kampung Wirausaha Simpang Tiga) Jombang. Laporan Program Hibah Internal Pengabdian Kepada Masyarakat Periode Ganjil

2015/2016 Unipdu

Widyati. 2007. Kreasi Macrame Tali Kur.

Surabaya: Tiara Aksa

Zimmerer W, Thomas \& Norman M. Scarborough. 2008. Kewirausahaan dan Manajemen Usaha Kecil, Edisi 5 Buku 1. Jakarta: Salemba Empat

---, Thomas \& Norman M. Scarborough. 2009. Kewirausahaan dan Manajemen Usaha Kecil, Edisi 5 Buku 2. Jakarta: Salemba Empat 